INDEPENDENT JOURNAL OF MANAGEMENT \& PRODUCTION (IJM\&P)

http://www.ijmp.jor.br

v. 12, n. 4, May-June 2021

ISSN: 2236-269X

DOI: 10.14807/ijmp.v12i4.1338

\title{
COMPETITIVENESS INFLUENCE ON GLOBAL INNOVATION OF NATIONS: A CROSS-SECTIONAL ANALYSIS
}

\author{
Ronaldo Leão de Miranda \\ Universidade Regional de Blumenau - FURB, Brazil \\ E-mail: ronaldo_leaomiranda@hotmail.com \\ Luís Fernando Irgang dos Santos \\ Universidade Regional de Blumenau - FURB, Brazil \\ Universidade de Halmstad, Suécia \\ E-mail: luis.irgang@hotmail.com \\ Giancarlo Gomes \\ Universidade Regional de Blumenau - FURB, Brazil \\ E-mail: giancarlog@furb.br \\ Iara Regina dos Santos Parisotto \\ Universidade Regional de Blumenau - FURB, Brazil \\ E-mail: iaraparisotto@furb.br
}

Submission: 5/4/2020

Revision: 6/3/2020

Accept: 7/3/2020

\section{ABSTRACT}

Innovation has been recognized as one of the main determinants of nation's economic development and has been adopted as a main tool for adding value and achieving sustainable competitive advantage. In order to understand the influence of global competitiveness on global innovation of nations, this study analyzed some indexes of 133 countries using a multiple linear regression analysis. The results suggested that global competitiveness influences the innovativeness of nations significantly and positively. Higher education and training was the competitiveness indicators that most influenced in innovation of nations.

Keywords: Innovation; Global Innovation Index; Competitiveness; Global Competitiveness Index. 
DOI: 10.14807/ijmp.v12i4.1338

\section{INTRODUCTION}

In the current literature, there is a growing interest in the role of innovation in the economic development of countries. Innovation has been recognized as a major determinant of economic development among nations (Dutta et al., 2018; Kaynak, Altuntas \& Dereli, 2017). Innovative countries are able not only to increase their productivity and improve international competitiveness, but also to raise economic growth and the population living standards (Kostoska \& Hristoski, 2017). As they approach the frontiers of knowledge, countries find in innovation the best alternative to create added value and achieve sustainable competitive advantage (Farinha, Ferreira \& Nunes, 2018).

The globalization effects impose the need to broadly assess the level of countries' economic development in order to identify factors that may determine the growth of one country against another (Zos-Kior et al., 2017). In an increasingly competitive global economy, innovation is a key factor in ensuring the progress and prosperity of nations (Kaynak et al., 2017). In this sense, composite indexes such as the Global Innovation Index and the Global Competitiveness Index have been increasingly used in academic research in order to compare countries' social and economic development.

The multilateral relationship between innovation and global competitiveness has been the focus of several studies in the last decade. Huang (2011) analyzed how technology competencies interact with the competitive environment and affect innovation. Fonseca and Lima (2015) investigated the correlation between social sustainability, innovation and competitiveness by adopting as unit of analysis the ten best ranked countries in these dimensions from 2013 to 2014. Zoroja (2015) analyzed the influence of innovations usage in information and communication technology (ICT) on the competitiveness of European countries.

Davydova, Ibatullina and Pachkova (2016) used innovation and competitiveness indexes to study the innovative investment development in BRICS countries. Recently, Cinicioglu et al. (2017) applied Bayesian Networks to evaluate the simultaneous interaction of competitiveness indicators in 148 countries and their innovative performance. Yordanova and Stoimenova (2020) analyzed the linkage between innovation on a country level and competitiveness of universities in 44 countries and their 1394 universities.

Although previous studies have provided valuable information on innovation from a perspective of global competitiveness, they have focused extensively on the context of 
INDEPENDENT JOURNAL OF MANAGEMENT \& PRODUCTION (IJM\&P)

http://www.ijmp.jor.br

v. 12, n. 4, May-June 2021

ISSN: 2236-269X

DOI: $10.14807 /$ ijmp.v12i4.1338

European countries. Therefore, there is a need to extend the analysis to a larger and more heterogeneous sample, including not only developed countries from Europe, which have high levels of innovativeness and competitiveness, but also developing countries from other regions with different economic and social contexts. To fill this gap, this study aims to analyze the influence of competitiveness on global innovation of nations. Thus, this study contributes to the academic debate on innovation and competitiveness of nations and provides more broad and actual results through quantitative methods.

The remainder of this paper is organized as follows. First, we provide an overview of the related literature on innovation and competitiveness, highlighting the concepts that guide the study. Second, we present a theoretical background, presenting a discussion around relevant studies. Third, we describe the research methods employed in this study. Next, we present and discuss the findings. Later, we conclude the study, presenting limitations and avenues for future research.

\section{LITERATURE REVIEW}

\subsection{Innovation}

There is no consensus in literature on the definition of innovation. Several authors have been trying to improve the concept of innovation from macroeconomic, microeconomic, social, environmental, cultural and political perspectives. At microeconomic levels, innovation can be defined as the successful of new knowledge development and application, and the knowledge transformation of into results (Cinicioglu et al., 2017). In a broad sense, Freeman (1987) proposed that innovation does not only refer to the individual work of companies, but also involves the level of collective effort at which governments and institutions perform functions to enable generation and diffusion of innovation in a national economy. Edquist (2010) concludes that the economic, political, social, organizational, institutional and other factors that influence the development, diffusion and use of innovations correspond to a national innovation system.

Due to a highly competitive environment and scenarios of successive global economic crises experienced in recent decades, innovation has been an important alternative in the adoption of countries' economic development strategies. In addition to providing higher growth rates, innovation also contributes to reducing a country's trade deficit, especially as it reduces the need to import technology and knowledge (Erciş \& Ünalan, 2016; Petrakis, Kostis \& Valsamis, 2015). In this sense, good national innovation systems afford financial resources, 
INDEPENDENT JOURNAL OF MANAGEMENT \& PRODUCTION (IJM\&P)

http://www.ijmp.jor.br

v. 12, n. 4, May-June 2021

ISSN: 2236-269X

DOI: 10.14807/ijmp.v12i4.1338

incentive policies, efficient institutions and other internal mechanisms that favor the development of innovations and reduce a need for imports (Ezell, Nager \& Atkinson, 2016; Freeman, 1987).

In order to measure and compare innovation rates at national level, several indicators are periodically prepared by international organizations. These include the Global Innovation Index - GII, which is provided by the International Business School in cooperation with Cornell University and the World Intellectual Property Organization - WIPO. This index is compiled based on 80 indicators that characterize the level of innovative activity in national economies.

To obtain this index, innovative capacities and institutional conditions for implementation of innovations are considered. The index is calculated by the weighted sum of scores from two indicator groups: available resources and institutional conditions for implementation of the innovation activity; and results obtained from the innovation activity (Kudryavtseva et al., 2016). In its latest edition, the GII report has indicated that Switzerland, the Netherlands, Sweden, the United Kingdom, Singapore, the United States, Finland, Denmark, Germany and Ireland as the 10 most innovative countries (Dutta et al., 2018).

\subsection{Competitiveness}

The term competitiveness has historically been used to relate companies and nations in terms of costs. For example, according to Rosenbaum (2011), competitiveness is determined by the level of productivity, which will also determine the sustainable level of prosperity of a nation. A broader interpretation suggests that competitiveness is not just an accounting outcome of cost-effectiveness, but involves the structure, processes, and skills of an organization or country (Aiginger \& Vogel, 2015).

Habánik, Kordoš and Hošták (2016) conclude that competitiveness is reflected in a nation's economic performance, productivity, employment and other social and political spheres. In this study, the concept suggested by The World Economic Forum (WEF) was adopted, which defines global competitiveness as the set of institutions, policies and factors that determine a country's level of productivity (Schwab, 2018).

Since 2004, the WEF has been preparing the Global Competitiveness Report annually, which contains the GCI - Global Competitiveness Index. This index has been one of the most widely used indicators among academics, political and business leaders (Schwab, 2018). GCI assesses a country's competitive environment based on its ability to ensure sustainable economic growth and the prosperity level of its population (Habánik et al., 2016). 
INDEPENDENT JOURNAL OF MANAGEMENT \& PRODUCTION (IJM\&P)

http://www.ijmp.jor.br

v. 12, n. 4, May-June 2021

ISSN: 2236-269X

DOI: $10.14807 /$ ijmp.v12i4.1338

The index also measures microeconomic and macroeconomic fundamentals and allows the comparative classification of competitiveness among nations (Lall, 2001), analyzing trends across countries and the causes of changes in key components of global competitiveness (ZosKior et al., 2017). In its latest edition, the Global Competitiveness Report highlighted the United States, Singapore, Germany, Switzerland, Japan, the Netherlands, Hong Kong, the United Kingdom, Sweden and Denmark in the TOP 10 of the world's most competitive countries (Schwab, 2018).

GCI is a composite index based on 113 indicators that reflect the competitiveness of countries. $70 \%$ of the variables included in this index represent qualitative data obtained from a questionnaire applied to companies top managemers from several economy sectors. The remaining $30 \%$ are quantitative data based on official statistical reports and research results from international institutions (Kudryavtseva et al., 2016). As a result, GCI provides a synthetic competitiveness framework, considering simultaneously 12 pillars that measure different dimensions of competitiveness.

These pillars are grouped into 3 sub-indexes, which correspond to three stages of development: sub-index of factors or basic requirements (I), sub-index of efficiency enhancers (II) and sub-index of innovation and sophistication factors (III) (Kostoska \& Hristoski, 2017; Pérez-Moreno, Rodríguez \& Luque, 2016). These pillars are assigned scores from 1 to 7 and these scores are aggregated to determine the overall global competitiveness index of countries (Dima et al., 2018). Figure 1 illustrates the global competitiveness index framework.

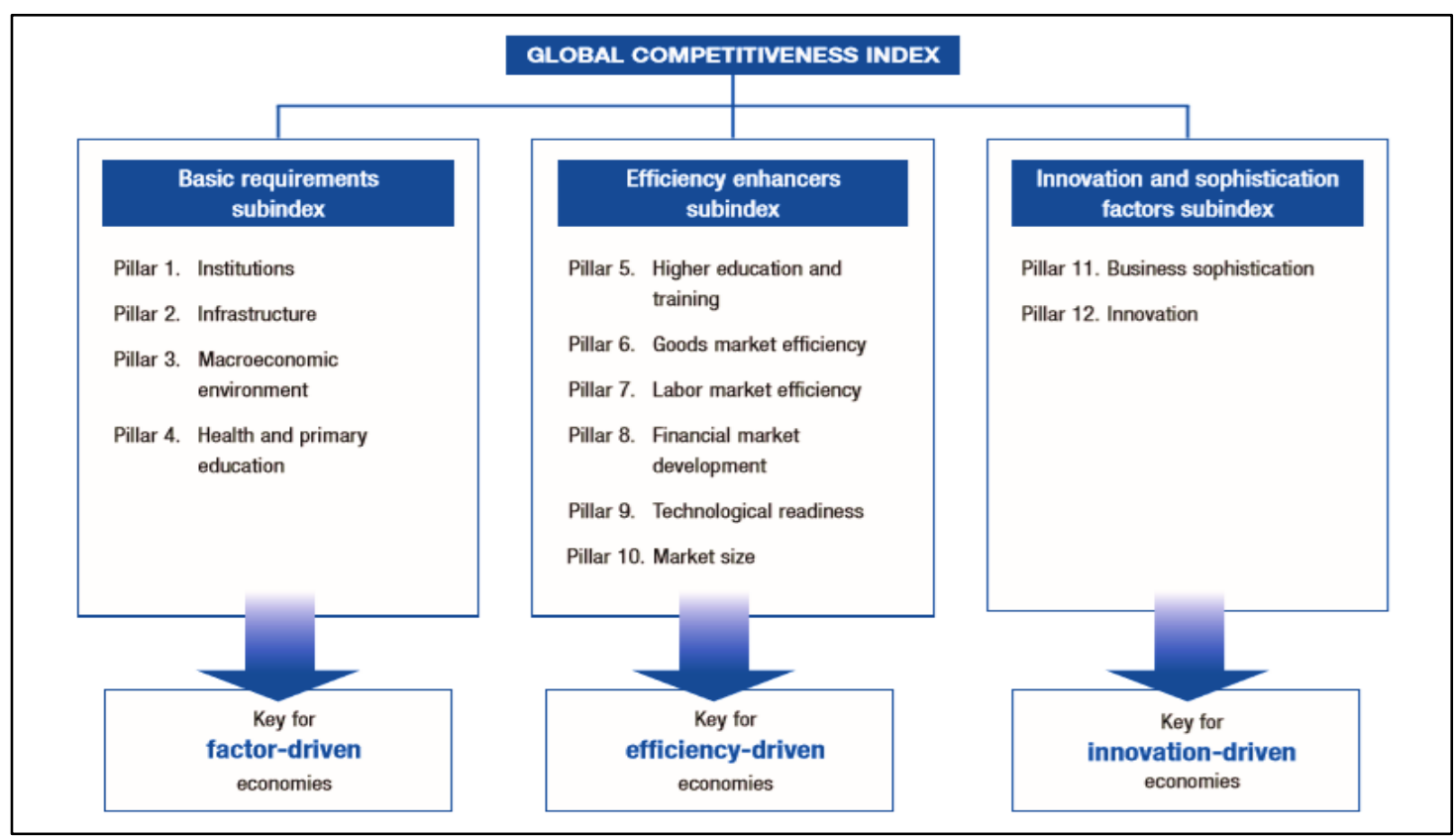

Figure 1: Global Competitiveness Index framework. Source: Adapted from Schwab (2018). 
In the first stage, economy is factor driven and countries compete based on their factor resources such as cheap labor and natural resources. In this phase, competitiveness occurs from the use of low production and marketing costs of lower priced products and services (Huggins \& Izushi, 2015). Maintaining competitiveness at this stage of development depends mainly on well-functioning public and private institutions (P1), well-developed infrastructure (P2), a stable macroeconomic environment (P3) and a healthy workforce with at least basic education (P4) (Pérez-Moreno et al., 2016).

At the efficiency-driven stage, wage costs tend to increase. Thus, to remain competitive, countries need to increase efficiency, especially in the workforce and through the use of technologies (Huggins \& Izushi, 2015). Competitiveness is driven by higher education and training (P5), efficient goods markets (P6), well-functioning labor markets (P7), developed financial markets (P8), ability to leverage the benefits of existing technologies ( P9), and a large internal or external market (P10) (Pérez-Moreno et al., 2016).

Finally, at the innovation stage, wage levels rise further. Thus, competitiveness results from creation of new and different products and the use of more sophisticated (P11) and innovative (P12) production processes (Huggins \& Izushi, 2015; Pérez-Moreno et al., 2016).

\section{THEORETICAL BACKGROUND}

In order to identify previous studies on innovation and global competitiveness of nations, Scopus database was used, because it is an international reference for scientific research. Google Scholar was also used as a research tool. The search keywords used were “Innovation”, “Global Innovation Index”, “Competitiveness” and “Global Competitiveness Index”.

Among the publications from 2010 to 2018, the most similar study found was from Cinicioglu et al. (2017), who applied the Bayesian Networks and cluster analysis to assess the simultaneous interaction of countries' competitiveness indicators and their innovative performance, providing a stepwise analysis to show how a country can reach higher innovation levels. The results suggested that business sophistication and higher education and training are the competitiveness indicators that most affect countries' level of innovation.

Kudryavtseva et al. (2016) developed a comparative analysis of the innovative development level among European Union countries and Russia. The authors used the GCI and the GII and employed a technique of positioning national innovation systems by integral cost 
INDEPENDENT JOURNAL OF MANAGEMENT \& PRODUCTION (IJM\&P)

http://www.ijmp.jor.br

v. 12, n. 4, May-June 2021

ISSN: 2236-269X

DOI: 10.14807/ijmp.v12i4.1338

and benefit indices of innovation activity, through the European innovation panel. The sample countries were grouped into homogeneous clusters according to their innovation and competitiveness characteristics. Finally, the authors compared development trends and the effectiveness of innovation policy common to the countries in each cluster.

Davydova et al. (2016) evaluated the relationship of several composite indicators from BRICS countries (Brazil, Russia, India, China, and South Africa) with the innovative investment development of these countries. The results indicated that GII and GCI have a high correlation factor. This suggests that the greater the competition, the higher the level of innovative development in the sample countries.

Fonseca and Lima (2015) investigated the correlation among social sustainability, innovation and competitiveness, adopting as a unit of analysis the ten best ranked countries in these three related dimensions in 2013 and 2014. The results indicated a high correlation among these three dimensions. However, considering this homogeneous sample of the best ranked countries in all performance indicators, high correlation coefficients are expected, which represents a limitation of the study. Another limitation concerns the composition of these indicators. The authors could consider all the factors that compose these indicators and develop a more sophisticated analysis by testing the relationship between the variables of each index.

Petrakis et al. (2015) analyzed the impact of culture on innovation and competitiveness in 24 European countries from 2008 to 2013, during the period known as "The Great Recession”. The authors considered cultural factors related to uncertainty, trust, creativity and organizational structure and grouped the sample countries into 2 clusters: countries with antiinnovation culture and countries with pro-innovation culture. The influence of cultural factors on innovation and global competitiveness was tested using ordinary least squares regressions. The results showed that countries with a pro-innovation culture present better performance in innovation and competitiveness indicators. However, the study disregards the possible correlation between the innovation and competitiveness variables in the analysis.

In contrast to other studies, Farinha et al. (2018) defined competitiveness as a dependent variable and analyzed innovation and entrepreneurship effects on the competitiveness of nations. A conceptual model of competitiveness was tested by applying descriptive statistics, structural equation modeling and hierarchical cluster analysis. The results pointed out that the factors that composed innovation, such as innovation capacity, R\&D spending and quality of scientific research institutions are the ones that most influence the competitiveness. The study 
DOI: $10.14807 /$ ijmp.v12i4.1338

also reveals a strong link between innovation and entrepreneurship with economic growth and competitiveness.

Zoroja (2015) analyzed the influence of innovations in information and communication technology (ICT) on the competitiveness among European countries. Through panel data analysis for the period 2007-2011, the study suggested that ICTs positively and significantly influence the global competitiveness. However, European countries have high scores on global competitiveness and ICT use rates, which in fact suggests high correlation coefficients between the variables analyzed.

Yordanova and Stoimenova (2020) analyzed weather educational innovation leads to university competitiveness by identifying the dimensions of universities competitiveness based on the global rankings available. The authors highlighted whether educational innovation is included and measured somehow given its mainstream recognition for university competitiveness.

Dima et al. (2018) also defined competitiveness as a dependent variable and, based on Pearson's regression models, analyzed the influence of knowledge economy indicators on the competitiveness of European Union countries. The results showed that innovation and education are the factors that most promote the competitiveness of EU countries.

There is a great interest on literature to analyze the innovation phenomenon from a perspective of global competitiveness. However, it is necessary to conduct a broad study with more recent indicators and to extend an analysis to a larger and more heterogeneous sample, including, for example, developing countries that have different economic and social structures than most European countries. To fill this gap, this study aims to analyze the influence of competitiveness on global innovation in several countries. Next session presents the methods employed in this study.

\section{RESEARCH METHODS}

In order to to analyze the influence of global competitiveness on global innovation, a quantitative approach and a descriptive technique were employed in this study. The data about innovation of nations were collected from the Global Innovation Index Report 2018 (Dutta et al., 2018). The data about global competitiveness were collected from The Global Competitiveness Report (Schwab, 2018). Through both databases, it was possible to gather indicators from 133 countries (see Appendix 1). Finally, data were tabulated using SPSS ${ }^{\circledR}$ software, version 14. 
DOI: 10.14807/ijmp.v12i4.1338

According to Aiginger and Vogel (2015) an adoption of global performance indicators composed of several indicators, can potentially reduce measurement errors. An analysis of these indicators allows a generation of information that can be used for formulation or improvement of government policies or international investment strategies by the public and private initiative (Lall, 2001; Nasierowski, 2016).

Data analysis was based on descriptive statistics and linear regression, which allows verifying and measure how model variables are related (Hair et al., 2009). Equation 1 describes the relationship between the dependent and independent variables adopted in the model.

$$
\begin{gathered}
\text { Equation 1: } \mathbf{G I I}_{i t}=\beta_{0}+\beta \mathrm{GCI}_{i t}+\beta \mathrm{P} 1_{i t}+\beta \mathrm{P} 2_{i t}+\beta \mathrm{P} 3_{i t}+\beta \mathrm{P} 4_{i t}+\beta \mathrm{P} 5_{i t}+\beta \mathrm{P} 6_{i t}+ \\
\beta \mathrm{P}_{i t}+\beta \mathrm{P} 8_{i t}+\beta \mathrm{P} 9_{i t}+\beta \mathrm{P} 10_{i t}+\beta \mathrm{P} 11_{i t}+\varepsilon
\end{gathered}
$$

In Equation 1, the dependent variable is represented by GII. $\beta_{0}$ represents the constant, while independent variables are represented by the Global Competitiveness Index $\left(\beta \mathrm{GCI}_{i t}\right)$ and its 11 pillars $\left(\beta \mathrm{P}_{i t}\right)$. The error of model is represented by $\varepsilon$.

For this study, the scores already provided by the sources were used. It was not necessary to standardize the data, since all the pillars were calculated on a scale ranging from 1 to 7 . Therefore, this study has not propose to validate constructs or dimensions, nor test the reliability of indicators, since the pillars have the same measurement score.

The next session presents the results and discussions regarding data analysis.

\section{FINDINGS}

In order to identify the influence of global competitiveness on innovation of nations, initially a descriptive statistic technique was performed. Table 1 describes the means, standard deviation and number of cases analyzed.

Table 1: Descriptive Statistics.

\begin{tabular}{lccc}
\hline Variables & Mean & Standard Deviation & N \\
\hline GCI - Global Competitiveness Index & 4.2 & 0.70 & 133 \\
P1 - Institutions & 4.0 & 0.87 & 133 \\
P2 - Infrastructure & 4.1 & 1.21 & 133 \\
P3 - Macroeconomic Environment & 4.6 & 1.01 & 133 \\
P4 - Health and Primary Education & 5.5 & 0.87 & 133 \\
P5 - Higher Education and Training & 4.3 & 1.03 & 133 \\
P6 - Goods Market Efficiency & 4.3 & 0.57 & 133 \\
P7 - Labor Market Efficiency & 4.2 & 0.60 & 133 \\
P8 - Financial Market Development & 4.0 & 0.75 & 133 \\
P9 - Technological Readiness & 4.2 & 1.25 & 133 \\
P10 - Market Size & 3.9 & 1.16 & 133 \\
P11 - Business Sofistication & 4.1 & 0.73 & 133 \\
\hline
\end{tabular}


INDEPENDENT JOURNAL OF MANAGEMENT \& PRODUCTION (IJM\&P)

http://www.ijmp.jor.br

v. 12, n. 4, May-June 2021

ISSN: 2236-269X

DOI: $10.14807 /$ ijmp.v12i4.1338

The average indexes range from 39 to GII and 42 to GCI, with a standard deviation of 1.25 and 0.70 , respectively. The indicators that composed the competitiveness of nations range from the lowest average of innovation (3.5) to the highest average of health and education (5.5), with standard deviations of 0.86 and 0.87 respectively.

Before verifying the possible influence from global competitiveness on global innovation indexes, a set of assumptions to prove the possibility of performing a linear regression was validated: diagnosis of serial autocorrelation in residuals, tests of residues normality and homoscedasticity and the coefficients linearity (Hair Jr. et al., 2005).

The Durbin-Watson test presented a value equal to 1.914 attesting to the non-existence of serial autocorrelation in the residuals. The Kolmogorov-Smirnov test revealed an acceptable level of significance of up to 5\% conferring normality in the waste distribution (Maroco \& Bispo, 2003). The inflation factor of the variance resulted in VIF $<10$, which indicates that there is no multicollinearity of the predictor variables (Hair et al., 1999).

The analysis of variance, provided through the Anova Test, also confirmed that the model is adequate for the study proposal (Sig <0.005). It means that the indicatores of competitiveness are predictives of the global innovation. The regression coefficient of adjustment $\left(\mathrm{R}^{2}=0.622\right)$ showed that approximately $62.2 \%$ of the total variance of global innovation can be explained by the combination of competitiveness indicators (Hair Jr. et al., 2005). Finally, the linear regression coefficients are presented in Table 2.

Table 2: Linear regression coefficients.

\begin{tabular}{lccccc}
\hline \multirow{2}{*}{ Model } & \multicolumn{2}{c}{$\begin{array}{c}\text { Non-Standardized } \\
\text { Coefficients }\end{array}$} & $\begin{array}{c}\text { Standardized } \\
\text { Coefficients }\end{array}$ & T & Sig. \\
\cline { 2 - 4 } & $\mathbf{B}$ & $\begin{array}{c}\text { Standard } \\
\text { Error }\end{array}$ & Beta & & .002 \\
\hline (Constant) & -1.490 & .468 & & -3.183 & .000 \\
GCI - Global Competitiveness Index & .935 & .094 & .650 & 9.941 & .000 \\
P1 - Institutions & .724 & .064 & .696 & 11.252 & .000 \\
P2 - Infrastructure & .670 & .090 & .538 & 7.417 & .000 \\
P3 - Macroeconomic Environment & .801 & .103 & .557 & 7.799 & .000 \\
P4 - Health and Primary Education & .842 & .076 & .688 & 11.026 & .000 \\
P5 - Higher Education and Training & 1.382 & .146 & .632 & 9.475 & .000 \\
P6 - Goods Market Efficiency & 1.109 & .153 & .530 & 7.258 & .000 \\
P7 - Labor Market Efficiency & .824 & .125 & .493 & 6.589 & .000 \\
P8 - Financial Market Development & .699 & .062 & .699 & 11.351 & .000 \\
P9 - Technological Readiness & .389 & .087 & .360 & 4.488 & .000 \\
P10 - Market Size & 1.170 & .108 & .683 & 10.866 & .000 \\
P11 - Businees Sofistication & 1.045 & .087 & .717 & 11.975 & .000 \\
\hline
\end{tabular}

Source: Research data (2019). 
DOI: 10.14807/ijmp.v12i4.1338

The first column of Table 2 indicates the constant and independent variables of the model, which are followed by estimates of their coefficients, beta and standard error (nonstandard), standardized coefficients (Beta), t-test and model significance. From the nonstandard coefficients (B) and considering all the significant coefficients ( Sig $\leq 0.05$ ), it is possible to determine the equation of the model:

$$
\begin{array}{r}
\text { Equation 2: } \mathbf{G I I}_{i t}=-1,49++0,935(\mathrm{IGC})_{i t}+0,724(\mathrm{P} 1)_{i t}+0,67(\mathrm{P} 2)_{i t}+0,801(\mathrm{P} 3)_{i t}+ \\
\begin{array}{c}
0,842(\mathrm{P} 4)_{i t}+1,382(\mathrm{P} 5)_{i t}+1,109(\mathrm{P} 6)_{i t} \\
+0,824(\mathrm{P} 7)_{i t}+0,699(\mathrm{P} 8)_{i t}+0,389(\mathrm{P} 9)_{i t}+1,17(\mathrm{P} 10)_{i t} \\
+1,045(\mathrm{P} 11)_{i t}+\varepsilon
\end{array}
\end{array}
$$

From the results, it can be inferred that when the GII increases by $1 \%$, there is an increase in both the GCI and its indicators. Thus, regarding the influence of GCI on GII, the coefficient (B) found is 1.27. It means that if each percentage point that GII increases, GCI increases 1.27. In this sense, when analyzing the explanatory power of the independent variable, GCI contributes to the explanation of GII by 0.714 .

Analyzing individually the relationship of the pillars from GCI, it can be stated that all indicators significantly and positively influence GII. The pillar that most impacts GII is P5 (higher education and training). This finding is in line with the research by Yordanova and Stoimenova (2020), as education has a fundamental role in generating innovation. Yordanova and Stoimenova (2020) conclude that competitiveness is important and generating educational innovations is essential to achieve innovation performance at the national level.

This result proves the explanations of Dima et al. (2018), which states that a welleducated and qualified population is essential for knowledge transformation into innovation. The other pillars that most impact GII are: P10 (market size), P6 (goods market efficiency) and P11 (business sophistication). This result is similar to the study by Cinicioglu et al. (2017), who suggest that business sophistication and higher education and training are the competitiveness indicators that most affect countries' level of innovation.

In contrast, the pillars that least influenced the composition of GII were: P9 (technological readiness), P2 (infrastructure), P8 (financial market development) and P1 (institutions). Such result contradicts, in part, the statements of Ezell et al. (2016), who suggest that to achieve good levels of innovation, a country needs financial incentives, efficient institutions and incentive policies.

In general, based on the statistical test employed in the analysis, the empirical results indicate that there is influence of indicators that compose countries' competitiveness on global 
DOI: 10.14807/ijmp.v12i4.1338

innovation, since the increase of one index implies the increase of another, which corroborates with the findings of Cinicioglu et al. (2017), Davydova et al. (2016) and Fonseca and Lima (2015).

\section{FINAL CONSIDERATIONS}

This study aimed at analyzing the influence of competitiveness on global innovation of nations. To test this relationship, a multiple linear regression analyses was employed, which proved the relationship of influence of the pillars of competitiveness on the countries' overall innovation index. By analyzing the regression coefficient of adjustment $\left(\mathrm{R}^{2}=0.622\right)$, it can be inferred that approximately $62.2 \%$ of the total variance of global innovation can be explained by the combination of competitiveness indicators. It is important to understand that the relationship between competitiveness indicators and the level of innovation in a country is a two-way relationship, rather than a unidirectional one, in which innovation and competitiveness interact (Cinicioglu et al., 2017).

When analyzing the influence of the GCI on the GII, the coefficient (B) resulted in 1.27, which demonstrates that at each percentage point that the GII increases, the GCI increases in the same proportion. When analyzing the indicators that compose the GCI, it can be inferred that if GII increases in one percent, the P6 (goods market efficiency) increases in 1.382. This result confirms the study of Huggins and Izushi (2015), which advocates that in order to maintain high competitiveness, countries need to increase the efficiency, especially in the workforce and through the use of technologies.

This study has some limitations. First, the adoption of secondary data to analyze innovation and global competitiveness may be conditional and contain some bias in the methods used by the organizations providing the indicators (Cinicioglu et al., 2017).

Second, an analysis of compound indices that are calculated from similar data series and similar parametric methods tends to generate high correlation factors and to present a high level of statistical significance (Nasierowski, 2016).

Third, for analysis purposes, an unidirectional relationship between competitiveness and innovation was considered. For future research, it is suggested that the multilateral relationship of these indicators be investigated to obtain a more sophisticated and complete analysis of an interaction dynamics of constructs. 
DOI: $10.14807 /$ ijmp.v12i4.1338

\section{REFERENCES}

Aiginger, K., \& Vogel, J. (2015). Competitiveness: from a misleading concept to a strategy supporting Beyond GDP goals. Competitiveness Review, 25(5), 497-523.

Cinicioglu, E. N., Ulusoy, G., Önsel Ekici, Ş., Ülengin, F., \& Ülengin, B. (2017). Exploring the interaction between competitiveness of a country and innovation using Bayesian networks. Innovation and Development, 7(2), 175-209.

Davydova, A. A., Ibatullina, A. A., \& Pachkova, O. V. (2016). Estimation of innovativeinvestment development of the countries of the brics group. Journal of Economics and Economic Education Research, 17, 105.

Dima, A., Begu, L., Vasilescu, M., \& Maassen, M. (2018). The relationship between the knowledge economy and global competitiveness in the European Union. Sustainability, 10(6), 1706.

Dutta, S., Reynoso, R. E., Garanasvili, A., Saxena, K., Lanvin, B., Wunsch-Vincent, S., \& Guadagno, F. (2018). The global innovation index 2018: Energizing the World with Innovation. Global Innovation Index 2018, 1.

Edquist, C. (2010). Systems of innovation perspectives and challenges. African Journal of Science, Technology, Innovation and Development, 2(3), 14-45.

Erciş, A., \& Ünalan, M. (2016). Innovation: A comparative case study of Turkey and South Korea. Procedia-Social and Behavioral Sciences, 235, 701-708.

Ezell, S. J., Nager, A., \& Atkinson, R. D. (2016). Contributors and detractors: ranking countries' impact on global innovation. Information Technology \& Innovation Foundation, January.

Farinha, L., Ferreira, J. J., \& Nunes, S. (2018). Linking innovation and entrepreneurship to economic growth. Competitiveness Review: An International Business Journal, 28(4), 451-475.

Fonseca, L. M., \& Lima, V. M. (2015). Countries three wise men: Sustainability, Innovation, and Competitiveness. Journal of Industrial Engineering and Management, 8(4), 12881302.

Freeman, C. (1987). Technical innovation, diffusion, and long cycles of economic development. In The long-wave debate (pp. 295-309): Springer.

Habánik, J., Kordoš, M., \& Hošták, P. (2016). Competitiveness of Slovak economy and regional development policies. Journal of International Studies, 9(1), 144-155.

Hair, J. F., Anderson, R. E., Tatham, R. L., \& Black, W. C. (1999). Análisis multivariante. 491. Prentice Hall Madrid.

Hair, J. F., Black, W. C., Babin, B. J., Anderson, R. E., \& Tatham, R. L. (2009). Análise multivariada de dados. Bookman Editora.

Hair Jr, J. F., Anderson, R. E., Tatham, R. L., \& Black, W. C. (2005). Fundamentos de métodos de pesquisa em administração. Porto Alegre: Bookman.

Huang, K.-F. (2011). Technology competencies in competitive environment. Journal of Business Research, 64(2), 172-179.

Huggins, R., \& Izushi, H. (2015). The Competitive Advantage of Nations: origins and journey. Competitiveness Review, 25(5), 458-470. 
Kaynak, S., Altuntas, S., \& Dereli, T. (2017). Comparing the innovation performance of EU candidate countries: an entropy-based TOPSIS approach. Economic Research-Ekonomska Istraživanja, 30(1), 31-54.

Kostoska, O., \& Hristoski, I. (2017). ICTs and innovation for competitiveness: Evidence for Western Balkans vis-à-vis the European Union. Zbornik radova Ekonomskog fakulteta u Rijeci: časopis za ekonomsku teoriju i praksu, 35(2), 487-518.

Kudryavtseva, S. S., Shinkevich, A. I., Ostanina, S. S., Vodolazhskaya, E. L., Chikisheva, N. M., Lushchik, I. V., \& Khairullina, E. R. (2016). The methods of national innovation systems assessing. International Review of Management and Marketing, 6(2S), 225-230.

Lall, S. (2001). Competitiveness indices and developing countries: an economic evaluation of the global competitiveness report. World development, 29(9), 1501-1525.

Maroco, J., \& Bispo, R. (2003). Estatística aplicada às ciências sociais e humanas.

Nasierowski, W. (2016). Composite indexes economic and social performance: Do they provide valuable information? Foundations of Management, 8(1), 167-174.

Pérez-Moreno, S., Rodríguez, B., \& Luque, M. (2016). Assessing global competitiveness under multi-criteria perspective. Economic Modelling, 53, 398-408.

Petrakis, P. E., Kostis, P. C., \& Valsamis, D. G. (2015). Innovation and competitiveness: Culture as a long-term strategic instrument during the European Great Recession. Journal of Business Research, 68(7), 1436-1438.

Rosenbaum, E. (2011). Competitiveness rankings of European countries-How much do they tell us? Intereconomics, 46(2), 82-90.

Schwab, K. (2018). The Global Competitiveness Report 2018.

Yordanova, Z., Bozev, V., Stoimenova, B., \& Biolcheva, P. (2019, December). Innovation and Competitiveness of Universities-An Empirical Research. In European, Mediterranean, and Middle Eastern Conference on Information Systems (pp. 438-447). Springer, Cham.

Yordanova, Z., \& Stoimenova, B. (2020), Smart educational innovation leads to university competitiveness, S. Tiwari et al. (eds.), Smart Innovations in Communication and Computational Sciences, Advances in Intelligent Systems and Computing 1168, https://doi.org/10.1007/978-981-15-5345-5_17, Springer Nature Singapore Pte Ltd.

Zoroja, J. (2015). Fostering competitiveness in European countries with ICT: GCI agenda. International Journal of Engineering Business Management, 7(Godište 2015), 7-18.

Zos-Kior, M., Kuksa, I., Samoilyk, I., \& Storoška, M. (2017). Methodology for assessing globalisation development of countries. Economic Annals-XXI, 168(11-12), 4-8. 
INDEPENDENT JOURNAL OF MANAGEMENT \& PRODUCTION (IJM\&P)

http://www.ijmp.jor.br

v. 12, n. 4, May-June 2021

ISSN: 2236-269X

DOI: 10.14807/ijmp.v12i4.1338

APPENDIX 1: Sample of countries used in the study.

\begin{tabular}{|c|c|c|c|c|c|c|}
\hline Afghanistan & Cambodia & El Salvador & Ireland & Malaysia & Pakistan & Swaziland \\
\hline Albania & Cameroon & Estonia & Israel & Mali & Panama & Sweden \\
\hline Algeria & Canada & Ethiopia & Italy & Mauritania & Paraguay & Switzerland \\
\hline Angola & $\begin{array}{c}\text { Central } \\
\text { African } \\
\text { Republic }\end{array}$ & Finland & Jamaica & Mauritius & Peru & Tajikistan \\
\hline Argentina & Chad & France & Japan & Mexico & Philippines & Tanzania \\
\hline Armenia & Chile & Georgia & Jordan & Moldavia & Poland & Thailand \\
\hline Australia & China & Germany & Kazakhstan & Mongolia & Portugal & Togo \\
\hline Austria & Colombia & Ghana & Kenya & Montenegro & Romania & Tunisia \\
\hline Azerbaijan & $\begin{array}{c}\text { Congo } \\
\text { Republic }\end{array}$ & Greece & Kuwait & Morocco & Russia & Turkey \\
\hline Bangladesh & Costa Rica & Guatemala & Kyrgyzstan & Mozambique & Rwanda & Uganda \\
\hline Belarus & Croatia & Guiana & Laos & Myanmar & Saudi Arabia & Ukraine \\
\hline Belgium & Cuba & Guinea & Latvia & Namibia & Senegal & $\begin{array}{c}\text { United Arab } \\
\text { Emirates }\end{array}$ \\
\hline Benin & Cyprus & Honduras & Lebanon & Nepal & Serbia & United \\
\hline Bolivia & $\begin{array}{c}\text { Czech } \\
\text { Republic }\end{array}$ & Hungary & Lesotho & Netherlands & Slovakia & United States \\
\hline $\begin{array}{c}\text { Bosnia and } \\
\text { Herzegovina }\end{array}$ & $\begin{array}{c}\text { Denmark } \\
\text { Botswana }\end{array}$ & Iceland & Liberia & New Zealand & Slovenia & Uruguay \\
\hline Brazil & $\begin{array}{c}\text { Dominican } \\
\text { Republic }\end{array}$ & Indonesia & Macedonia & Niger & South Korea & Venezuela \\
\hline Bulgaria & Ecuador & Iran & Madagascar & Nigeria & Spain & Yemen \\
\hline Eurkina Faso & Egypt & Iraq & Malawi & Norway & Sri Lanka & Zambia \\
\hline
\end{tabular}

Source: Research data (2019). 